\title{
Perbandingan Perkembangan dan Kualitas Buah Tiga Aksesi Jeruk Pamelo (Citrus maxima (Burm.) Merr.)
}

\section{Comparison of Development and Quality of Fruit on Three Accession Pummelo Orange (itrus $\underline{\text { maxima }}$} (Burn.) Merr.).

\section{Dadang Hermansyah dan Slamet Susanto*}

\author{
Departemen Agronomi dan Hortikultura, Fakultas Pertanian, Institut Pertanian Bogor (Bogor Agricultural \\ University), Jl. Meranti, Kampus IPB Darmaga, Bogor 16680, Indonesia \\ Telp.\& Faks.62-251-869353 e-mail agronipb@indo.net.id \\ *Penulis untuk korespondensi: slmtsanto@gmail.com
}

Disetujui 14 Mei 2018 / Published online 21 Mei 2018

\begin{abstract}
Pummelo (Citrus maxima (Burn.) Merr.) has been cultivated in some areas of Indonesia, but pummelo development in Indonesia is still very limited. Pummelo development efforts are directed to the availability of superior cultivars. The objective of this research was to gain information about developmental and quality differences of fruit on three pummelo accession. This research was conducted at Cikabayan IPB from December 2015 to July 2016. The experiment used a randomized complete block design (RKLT) with single factor named accession (accession 1, accession 2 and accession 3) consisting of three replication. The results showed different diameter of accession 1 was that significantly higher than the other accessions. All accessions showed that fruit diameter continued to increase in early development but fruit grew slowly in the maturity period. Accession 1 also showed a higher different in fruit volume and weight than the other accessions, but in the smoothness of accession 1 differ markedly lower than the accession 3. Accession 2 a pul thickness of accession with the highest compared accession 1 and 3. The content of fruit juice on a different accession 1 were significantly higher than the accession 3 but not different with the accession 2. The content of the acid (ATT) on accession 2 is higher compared to the other accessions. Accession 1 had a higher ratio of PTT/ATT than the accession 2 and 3. Differences accession did not show significantly different on the edible portion, chlorophyll content and sugar content (PTT). Accession 1 is the best accession based on the criteriaof fruit size, juice content, and fruit flavor which has the lowest acid content.
\end{abstract}

Keywords: accession, fruit development, fruit quality, pummelo

\begin{abstract}
ABSTRAK
Pamelo (Citrus maxima (Burn.) Merr.) telah dibudidayakan di berbagai wilayah Indonesia, namun pengembangan pamelo di Indonesia masih sangat terbatas. Upaya pengembangan pamelo diarahkan pada ketersediaan kultivar unggul. Tujuan dari penelitian ini adalah memperoleh informasi perbedaan perkembangan dan kualitas buah pada tiga aksesi jeruk pamelo. Penelitian ini dilaksanakan di Kebun Percobaan Cikabayan IPB dari bulan Desember 2015 sampai Juli 2016. Percobaan menggunakan rancangan kelompok lengkap teracak (RKLT) dengan satu faktor yaitu aksesi (aksesi 1, aksesi 2, dan aksesi 3) yang terdiri atas 3 ulangan. Hasil penelitian menujukkan bahwa perbedaan diameter dari aksesi 1 secara signifikan lebih tinggi dari aksesi lainnya pada akhir pengamatan. Semua aksesi menunjukkan bahwa diameter buah terus meningkat di perkembangan awal namun perkembangan buah semakin lambat pada periode pematangan. Aksesi 1 juga menunjukkan hasil nyata lebih tinggi pada volume dan bobot buah dibanding aksesi lainnya namun pada kelunakan buah aksesi 1 berbeda nyata lebih rendah dibanding aksesi 3 . Aksesi 2 merupakan aksesi dengan tebal kulit buah paling tinggi dibanding aksesi 1 dan 3 . Kandungan jus buah pada aksesi 1 berbeda nyata lebih tinggi dibanding aksesi 3 namun tidak berbeda dengan aksesi 2. Kandungan asam/ATT pada aksesi 2 paling tinggi dibanding aksesi lainnya. Aksesi 1 memiliki rasio PTT/ATT lebih tinggi dibanding aksesi 2 dan 3. Perbedaan aksesi tidak menunjukkan hasil berbeda nyata pada bagian dapat dimakan, pigmen klorofil kulit buah, dan kandungan gula/PTT. Aksesi 1 adalah aksesi terbaik berdasarkan kriteria ukuran buah, kandungan jus, dan rasa buah yang memiliki kadar asam paling rendah.
\end{abstract}

Kata kunci : aksesi, kualitas buah, pamelo, perkembangan buah 


\section{PENDAHULUAN}

Jeruk pamelo (Citrus maxima (Burm.) Merr.) merupakan tanaman buah asli Indonesia yang bernilai ekonomi tinggi. Jeruk pamelo tersebar di berbagai wilayah di Indonesia dan memiliki beragam kultivar diantaranya Bali Merah, Cikoneng, Nambangan, Raja, Ratu, dan Pangkep. Plasma nutfah pamelo sangat beragam di Indonesia dengan nama daerah berbeda. Hanya beberapa kultivar jeruk pamelo yang dikembangkan padahal tidak kurang dari 24 kultivar pamelo yang telah dikenal masyarakat. Kultivar yang diproduksi secara komersial, antara lain 'Magetan', 'Nambangan', 'Raja', 'Ratu' dan 'Sri Nyonya'. Magetan, Sumedang dan Pangkep merupakan sentra utama jeruk pamelo (Rahayu, 2012).

Jeruk pamelo (Citrus maxima (Burm.) Merr.) dianggap sebagai salah satu dari tiga jenis jeruk yang asli disamping Citrus medica dan Citrus reticulata (Hynniewta et al. 2011). Jeruk pamelo tumbuh di daerah tropis sehingga jeruk pamelo potensial untuk dikembangkan di Indonesia namun produksinya masih fluktuatif, hal ini ditunjukkan pada produksi tahun 20112015 secara berurutan sebesar 97.069 ton, 113.388 ton, 106.344 ton, 141.296 ton, dan 111.753 ton (BPS, 2016). Berukuran besar, memiliki rasa segar, dan daya simpan yang lama sampai 4 bulan merupakan ciri khas dari jeruk pamelo (Susanto, 2004).

Kultivar unggul jeruk pamelo yang dirakit dan/atau diseleksi dari berbagai aksesi plasma nutfah yang tersedia merupakan salah satu faktor penentu keberhasilan pengembangan jeruk pamelo. Rahayu (2012) melaporkan bahwa kultivar 'Nambangan' merupakan salah satu kultivar jeruk pamelo yang paling banyak dibudidayakan di Indonesia. Toh et al. (2013) menyatakan bahwa jeruk pamelo mengandung beberapa senyawa antioksidan yang cukup tinggi, seperti senyawa fenol dan flavonoid. Memiliki warna jus merah, rasa getir rendah, mudah dikupas dan tidak berbiji merupakan kriteria buah jeruk pamelo yang potensial dikembangkan.

Jeruk pamelo mempunyai potensi untuk dikembangkan di Indonesia, namun pengembangannya masih terbatas. Menurut Rahayu (2012) upaya pengembangan pamelo diarahkan pada ketersediaan kultivar unggul yang menghasilkan buah tanpa atau sedikit biji, keragaan bibit yang baik, serta potensi pembungaan yang memadai untuk menjamin produktivitas dan kualitas buah yang tinggi. Kultivar unggul dapat diperoleh melalui seleksi plasma nutfah, hasil persilangan maupun pemanfaatan bioteknologi. Identifikasi perbedaan antar aksesi pamelo dapat dilihat berdasarkan ciriciri buahnya, antara lain ukuran dan bentuk buah, bentuk ujung dan pangkal buah, warna dan tekstur flavedo (epicarp), ketebalan dan warna albedo (mesocarp), warna endokarpium, warna dan rasa vesicula atau daging buah, aroma minyak atsiri, jumlah buah per pohon dan jumlah biji pada setiap buah (Suharsi, 2000).

\section{METODE PENELITIAN}

Penelitian ini dilaksanakan di Kebun Percobaan Cikabayan Bawah University Farm, Analisis laboratorium dilaksanakan di Departemen Agronomi dan Hortikultura IPB yakni Postharvest Laboratory dan dilaksanakan pada bulan Desember 2015 sampai bulan Juli 2016. Bahan yang digunakan dalam penelitian ini adalah tanaman jeruk pamelo tiga aksesi berbeda yang telah berproduksi untuk kedua kalinya, plastik pemberongsong, pupuk NPK 15:15:15, pupuk kandang dan senyawa kimia dalam analisis jeruk pamelo. Tinggi tanaman jeruk pamelo mencapai \pm 4 m dengan jarak tanam $4 \times 3 \mathrm{~m}$. Jenis pembungkus yang digunakan adalah kantong plastik ukuran $24 \mathrm{~cm}$ berwarna bening. Plastik pemberongsong dilubangi sebanyak 11 lubang pada bagian bawahnya dengan diameter $\pm 0.5 \mathrm{~cm}$ untuk sirkulasi udara. Peralatan yang digunakan meliputi timbangan analitik, jangka sorong, hand refraktrometer Atago DUE-PSH 10, penetrometer controller MK VI, centrifuge 5410, spektrofotometer Schimadzu UV-1 800, vortex, alat-alat pertanian, ATK, dan alat-alat dalam analisis kimia.

Penelitian menggunakan rancangan kelompok lengkap teracak (RKLT) dengan satu faktor yaitu aksesi (aksesi 1, aksesi 2, dan aksesi 3). Tiap perlakuan terdiri atas 3 ulangan dengan tiap unit percobaan menggunakan 5 buah sampel pamelo. Data hasil pengamatan dianalisis menggunakan uji $\mathrm{F}$ untuk mengetahui adanya pengaruh nyata antara perlakuan yang diuji. Jika terdapat pengaruh nyata, maka dilakukan uji lanjut Duncan Multiple Range Test (DMRT) pada taraf $\alpha=5 \%$. Perangkat lunak yang digunakan untuk analisis data adalah Microsoft Excel 2010 untuk rekapitulasi data dan SAS 9.0 untuk uji $F$ serta uji lanjut DMRT.

Pelaksanaan penelitian ini dimulai dengan pemeliharaan tanaman jeruk pamelo. Pemeliharaan tersebut meliputi pengendalian gulma dan pemupukan. Pengaturan nisbah jumlah daun:buah (nisbah jumlah daun diseragamkan 1:100) dilakukan pada saat buah berumur 3 minggu setelah antesis (MSA). Pemberongsongan 
buah dilakukan pada saat buah berumur 4 MSA dengan diameter buah $\pm 3.5 \mathrm{~cm}$. Semua buah jeruk pamelo dipanen pada umur 19 MSA.

Peubah pengamatan penelitian yang dilakukan ini meliputi pengamatan selama perkembangan buah dan setelah panen.
a. Selama perkembangan buah
Pengukuran diameter buah : pengamatan pengukuran diameter buah dilakukan pada sisi melintang (diameter melintang)
b. Panen

Pengamatan panen dilakukan pada kualitas eksternal dan internal buah.

1. Kualitas ekstenal buah, meliputi:

- Pigmen kulit buah : terdiri atas klorofil. Menurut Sims dan Gamon (2002) kandungan klorofil total diukur dengan menggunakan metode spektrofotometri.

- Kemulusan : diamati dengan cara skoring.

- Kelunakan buah : dilakukan dengan alat penetrometer elektrik controller MK VI berdasarkan daya penetrasi jarum terhadap kulit pamelo.

- Volume buah : menggunakan prinsip Hukum Archimedes, yakni dengan cara memasukkan buah jeruk pamelo ke dalam wadah yang berisi penuh air.

- Bobot buah : menggunakan timbangan analitik dan dinyatakan dalam gram $(\mathrm{g})$.

- Tebal kulit buah : rata-rata tebal kulit dari dua sisi diameter melintang buah (Susanto 2004).

- Bagian dapat dimakan (BDD) (\%) : diperoleh dari perbandingan bobot daging buah (g) Bobot buah (g)
2. Kualitas internal buah adalah kualitas dari daging buah, terdiri atas:

- Kandungan jus buah (\%) : diperoleh dari perbandingan volume air dari daging buah yang dihaluskan $(\mathrm{ml})$ dengan bobot daging buah $(\mathrm{g})$.

- Padatan terlarut total (PTT) : dilakukan dengan meneteskan perasan buah jeruk pada hand refraktrometer dan dibaca dalam satuan ${ }^{\circ}$ Brix.

- Asam tertitrasi total (ATT) : diukur menggunakan metode titrasi $\mathrm{NaOH}$ $0.1 \mathrm{~N}$ dengan larutan indikator phenolftalein (PP) (Nielson 1998).

- Rasio PTT/ATT : merupakan indeks kematangan buah. Semakin tinggi nilai rasio PTT/ATT menunjukkan bahwa buah semakin matang.

\section{HASIL DAN PEMBAHASAN}

\section{Perkembangan Buah Jeruk Pamelo}

Pengamatan buah jeruk pamelo yang dilakukan di lapangan menunjukan bahwa tidak semua buah dapat bertahan sampai panen. Buah yang dijadikan sampel mengalami kerontokan pada saat buah berumur 8-12 MSA, namun terdapat juga buah yang rontok ketika mendekati masa pematangan. Kerontokan buah tersebut disebabkan oleh serangan hama lalat buah. Lalat buah yang menyerang buah akan menusukkan telurnya ke dalam buah dan berkembang menjadi larva yang merusak jaringan dalam buah jeruk pamelo hingga rontok. Buah yang rontok masih dalam masa pembesaran buah (masa pembelahan sel) dan daging buah nya pun belum terlihat warna yang jelas (masih bening). Hal ini diakibatkan terlambatnya pemberongsongan buah sehingga hama lalat buah memasukkan telurnya sebelum pembrongsongan. Hampir setengah dari buah yang dilakukan pembrongsongan mengalami kerontokkan buah.

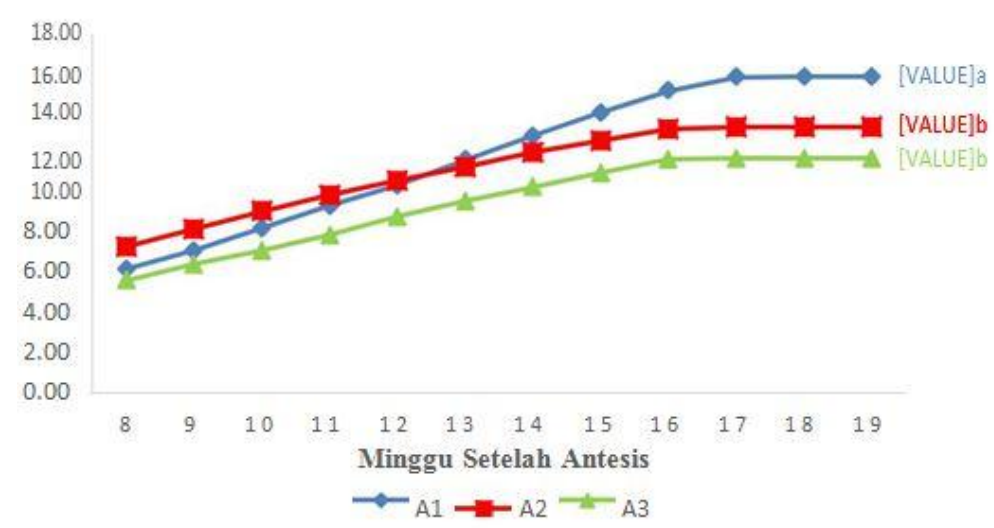

Gambar 1. Perkembangan diameter melintang buah jeruk pamelo 
Perbedaan aksesi menunjukkan hasil berbeda nyata pada peubah diameter melintang buah pada beberapa minggu pengamatan (Gambar 1). Diameter buah antar aksesi berbeda nyata pada saat $8,9,13,16,17,18$, dan 19 MSA, dan tidak nyata pada saat $10,11,12,14$, dan 15 MSA. Hasil uji lanjut menunjukkan bahwa aksesi 2 mempunyai diameter paling besar dibanding aksesi lainnya pada pengamatan 8 MSA. Selanjutnya pada pengamatan ke $9,10,11,12$, dan 13 MSA aksesi 2 mempunyai diameter lebih besar dibanding aksesi 3 namun tidak berbeda nyata dengan diamater aksesi 1 . Hasil uji lanjut juga menunjukkan diameter buah aksesi 1 nyata lebih besar dibandingkan aksesi 2 dan 3 pada pengamatan ke 16-19 MSA. Perbedaan aksesi ini menunjukkan perbedaan perkembangan diameter buah terutama pada masa buah mendekati siap panen yaitu setelah buah berumur 16 MSA. Perkembangan diameter buah telihat berbeda signifikan pada aksesi 1 yang diameter buah lebih tinggi dibanding aksesi lainnya. Semua aksesi menunjukkan perkembangan buah terus meningkat sampai buah berumur 16 MSA namun perkembangan relatif konstan sejak umur 16 MSA sampai buah siap dipanen. Buah akan mengalami perkembangan ukuran lebih cepat pada fase pembesaran sel dan selanjutnya akan melambat pada fase pematangan. Menurut Mahardika dan Susanto (2003) pertumbuhan buah jeruk pamelo berlangsung cepat pada awal pertumbuhan setelah dua bulan antesis dan mulai melambat sampai buah siap panen.

\section{Kualitas Buah Jeruk Pamelo}

Perbedaan aksesi tidak memberikan pengaruh berbeda nyata pada kemulusan, kelunakan, BDD, klorofil a dan b, total klorofil, dan PTT namun berbeda nyata pada rasio PTT/ATT serta berbeda sangat nyata pada volume buah, bobot buah, tebal kulit, diameter, kandungan jus, dan ATT. Rata-rata hasil uji lanjut pada kemulusan, kelunakan, dan volume buah ditunjukkan pada Tabel 1.

Tabel 1. Rata-rata kemulusan, kelunakan, dan volume buah

\begin{tabular}{lccc}
\hline Aksesi & Kemulusan $(\%)$ & Kelunakan $(\mathrm{mm} \mathrm{50}$ g-1 5 detik-1) & Volume buah $(\mathrm{ml})$ \\
\hline A1 & $58,50 \mathrm{a}$ & $17,610 \mathrm{~b}$ & $1717,33 \mathrm{a}$ \\
A2 & $48,84 \mathrm{a}$ & $21,786 \mathrm{ab}$ & $1027,28 \mathrm{~b}$ \\
A3 & $41,83 \mathrm{a}$ & $23,423 \mathrm{a}$ & $1096,87 \mathrm{~b}$ \\
\hline
\end{tabular}

Keterangan: Angka yang diikuti huruf berbeda pada kolom yang sama berbeda nyata berdasarkan hasil Duncan's multiple range test $(\mathrm{DMRT})$ pada taraf $\alpha=5 \%, \mathrm{~A} 1=$ Aksesi $1, \mathrm{~A} 2=$ Aksesi $2, \mathrm{~A} 3=$ Aksesi 3.

Hasil uji lanjut tidak menunjukkan tingkat kemulusan yang berbeda pada semua aksesi. Kemulusan dipengaruhi oleh tingkat kerusakan yang disebabkan oleh hama dan penyakit. Tingkat kemulusan buah antar aksesi juga tidak menunjukkan hasil yang berbeda nyata karena pada semua buah dilakukan pembrongsongan agar terhindar dari serangan hama. Kelunakan kulit buah pada aksesi 3 berbeda nyata lebih tinggi dibanding aksesi 1 namun tidak bebeda nyata dengan aksesi 2 . Kelunakan kulit buah umumnya berhubungan dengan tingkat kematangan buah. Hal ini menunjukkan buah pada aksesi 3 memiliki tingkat kematangan lebih tinggi dibanding aksesi 1 namun tidak nyata lebih tinggi pada aksesi 2 . Jeruk pamelo tergolong pada buah yang berkulit keras, pada stadia awal perkembangan buah kulit buah akan keras dan sedikit lunak pada stadia pematangan (Muramatsu et al.,1999).
Volume buah menunjukkan hasil yang berbeda nyata pada perlakuan aksesi. Aksesi 1 merupakan aksesi dengan volume buah paling besar dibandingkan dengan aksesi lainnya. Volume buah menunjukkan ukuran buah, semakin besar volume buah semakin besar ukuran buah. Ukuran buah paling besar yaitu buah pamelo aksesi 1 dibanding aksesi lainnya. Kalsum (2015) melaporkan bahwa terdapat hubungan korelasi positif antara total luas daun dan akumulasi karbohidrat daun terhadap bobot dan volume buah.

Peubah pengamatan penelitian lainnya yaitu bobot buah, tebal kulit, dan bagian dapat dimakan (BDD). Perbedaan aksesi juga menunjukkan adanya perbedaan yang nyata pada bobot buah dan tebal kulit namun tidak berpengaruh nyata pada bagian dapat dimakan (BDD) (Tabel 2). 
Tabel 2. Rata-rata bobot buah, tebal kulit buah, dan BDD

\begin{tabular}{lcccc}
\hline \multirow{2}{*}{ Aksesi } & \multirow{2}{*}{ Bobot buah $(\mathrm{g})$} & \multirow{2}{*}{ Tebal kulit $(\mathrm{cm})$} & $(\mathrm{g})$ & \multicolumn{2}{c}{ BDD } \\
\cline { 3 - 5 } & $1128,73 \mathrm{a}$ & $1,73 \mathrm{a}$ & $658,26 \mathrm{a}$ & $58,12 \mathrm{a}$ \\
A1 & $816,40 \mathrm{~b}$ & $1,67 \mathrm{a}$ & $461,46 \mathrm{a}$ & $60,99 \mathrm{a}$ \\
A3 & $810,27 \mathrm{~b}$ & $1,29 \mathrm{~b}$ & $489,33 \mathrm{a}$ & $60,42 \mathrm{a}$ \\
\hline
\end{tabular}

Keterangan: Angka yang diikuti huruf berbeda pada kolom yang sama berbeda nyata berdasarkan hasil Duncan's multiple range test $(\mathrm{DMRT})$ pada taraf $\alpha=5 \%, \mathrm{~A} 1=$ Aksesi 1, A2 = Aksesi 2, A3 = Aksesi 3 .

Bobot buah pada perlakuan aksesi 1 menunjukkan hasil nyata paling tinggi dibanding aksesi 2 dan 3. Hal ini berhubungan dengan ketersediaan asimilat yang dihasilkan oleh source untuk pembesaran buah sehingga terjadinya variasi bobot buah pada tiga aksesi tersebut. Variasi bobot buah pamelo tidak hanya terjadi antar aksesi, tetapi juga dalam satu aksesi, yang disebabkan oleh perbedaan nutrisi dan lingkungan tumbuh (Rahman et al., 2003). Tebal kulit pada aksesi 3 dari hasil uji lanjut menunjukkan hasil nyata lebih rendah dibanding aksesi lainnya. Tebal kulit pada aksesi 3 paling tipis, hal ini diduga karena berhubungan dengan ukuran buah yang paling kecil. Ukuran buah pada aksesi 1 merupakan paling besar dan mempunyai tebal kulit yang tebal. Ukuran buah dan tebal kulit mempunyai hubungan yang linier, ukuran buah yang lebih besar akan diikuti oleh peningkatan tebal kulit buah dan sebaliknya jika ukuran buah semakin kecil akan diikuti oleh kulit buah yang lebih tipis (Oliveira dan Resende, 2012). Bagian dapat dimakan (BDD) berdasarkan hasil uji lanjut tidak menunjukkan hasil yang berbeda nyata pada perlakuan aksesi yang berbeda. BDD semua perlakuan lebih dari separuh bobot buah, yakni lebih dari 50\%. Mahardika dan Susanto (2003) melaporkan bahwa BDD jeruk pamelo kultivar Nambangan kurang lebih separuh dari bobot buah. Bagian dapat dimakan pada buah pamelo bervariasi karena komponen buah setiap aksesi berbeda seperti kulit buah dan adanya biji pada setiap aksesi.

Tabel 3. menunjukkan pengamatan warna kulit buah dengan melakukan pengukuran kandungan pigmen klorofil. Klorofil adalah pigmen yang menyebabkan adanya warna hijau pada flavedo atau kulit buah. Pigmen warna hijau akan tinggi pada masa perkembangan buah namun akan berkurang pada masa pematangan buah karena klorofil yang tergedradasi. Secara visual semua aksesi yang diamati menunjukkan warna kulit buah hijau kekuningan (Gambar 4). Aksesi buah menunjukkan pengaruh hasil tidak berbeda nyata pada kandungan pigmen klorofil kulit buah.

Tabel 3. Rata-rata kandungan klorofil kulit buah jeruk pamelo

\begin{tabular}{cccc}
\hline Aksesi & Klorofil ${\mathrm{a}\left(\mathrm{mg} \mathrm{g}^{-1}\right)}^{-1}$ & Klorofil $\mathrm{b}_{\left(\mathrm{mg} \mathrm{g}^{-1}\right)}$ & Total klorofil $\left(\mathrm{mg} \mathrm{g}^{-1}\right)$ \\
\hline A1 & $0,06 \mathrm{a}$ & $0,03 \mathrm{a}$ & $0,08 \mathrm{a}$ \\
A2 & $0,05 \mathrm{a}$ & $0,02 \mathrm{a}$ & $0,07 \mathrm{a}$ \\
A3 & $0,04 \mathrm{a}$ & $0,02 \mathrm{a}$ & $0,06 \mathrm{a}$ \\
\hline
\end{tabular}

Keterangan: Angka yang diikuti huruf berbeda pada kolom yang sama berbeda nyata berdasarkan hasil Duncan's multiple range test $(\mathrm{DMRT})$ pada taraf $\alpha=5 \%, \mathrm{~A} 1=\mathrm{Aksesi} 1, \mathrm{~A} 2=\mathrm{Aksesi} 2, \mathrm{~A} 3=\mathrm{Aksesi} 3$.

Pigmen klorofil kulit buah jeruk pamelo terdiri dari klorofil a dan klorofil b. Klorofil a maupun klorofil $\mathrm{b}$ tidak menunjukkan perbedaan yang nyata pada setiap aksesi. Nilai rata-rata jumlah klorofil a kulit buah mencapai dua kali lipat dibanding nilai rata-rata klorofil $b$. Klorofil a merupakan komponen utama dari klorofil kulit buah. Klorofil kulit buah akan terdegradasi pada saat stadia pematangan buah yang menyebabkan konsentrasi klorofil pada kulit buah akan menurun (Rodrigo et al., 2013). Hal yang sama disampaikan Kalsum (2015), degradasi kandungan klorofil pada kulit buah berdampak pada warna kulit buah, semakin rendah konsentrasi klorofil maka warna hijau kulit buah akan semakin muda.
Hasil uji pada kandungan jus, ATT, dan rasio PTT/ATT berbeda nyata pada aksesi yang berbeda namun tidak berpengaruh nyata pada kandungan PTT (Tabel 4.). Kandungan jus pada aksesi 1 nyata lebih tinggi dibanding kandungan jus buah aksesi 3 berdasarkan uji lanjut namun tidak berbeda nyata dengan kandungan jus pada aksesi 2. Warna jus buah yang terdapat pada aksesi 1 dan aksesi 2 berwarna merah muda sedangkan pada aksesi 3 berwarna merah kekuningan. Kandungan jus ini diperoleh dari persentase rasio bobot sari buah dengan bobot daging buah. Persentase kandungan jus buah berkaitan dengan irigasi selama budidaya dan aktivitas air di dalam buah (Keshani et al., 2010). 
Tabel 4. Rata-rata kandungan jus, padatan terlarut total (PTT), asam tertitrasi total (ATT), dan rasio $\mathrm{PTT} / \mathrm{ATT}$

\begin{tabular}{cllrc}
\hline Aksesi & Kandungan jus $(\%)$ & PTT $\left({ }^{\circ}\right.$ Brix $)$ & ATT $(\%)$ & Rasio PTT/ATT \\
\hline A1 & $65,56 \mathrm{a}$ & $8,05 \mathrm{a}$ & $0,43 \mathrm{~b}$ & $21,10 \mathrm{a}$ \\
A2 & $63,23 \mathrm{ab}$ & $8,70 \mathrm{a}$ & $1,05 \mathrm{a}$ & $10,40 \mathrm{~b}$ \\
A3 & $60,60 \mathrm{~b}$ & $8,17 \mathrm{a}$ & $0,97 \mathrm{~b}$ & $10,30 \mathrm{~b}$ \\
\hline
\end{tabular}

Keterangan: Angka yang diikuti huruf berbeda pada kolom yang sama berbeda nyata berdasarkan hasil Duncan's multiple range test $(\mathrm{DMRT})$ pada taraf $\alpha=5 \%$, A1 =Aksesi 1, A2 = Aksesi 2, A3 = Aksesi 3.

Kandungan padatan terlarut total (PTT) tidak berbeda nyata pada perbedaan aksesi. Hal ini menunjukkan tingkat kemanisan jus buah setiap aksesi relatif sama yaitu berkisar $8{ }^{\circ}$ Brix. Kadar kemanisan pada tiga aksesi yang diamati tergolong masih rendah. Menurut Rahayu et. al. (2010) melaporkan bahwa tingkat kemanisan kultivar jeruk besar berkisar antara 8-12 ${ }^{\circ}$ Brix. Menurut Liliandra (2015) kadar kemanisan dipengaruhi oleh faktor-faktor seperti oleh kondisi iklim, teknik budidaya, genetik tanaman, tingkat kemasakan buah dan umur petik buah. Hasil uji lanjut juga menunjukkan bahwa perlakuan aksesi 2 merupakan aksesi dengan kandungan asam tertitrasi total (ATT) paling tinggi dibanding aksesi lainnya. Hal ini menunjukkan rasa buah, kandungan ATT yang tinggi menyebabkan buah menjadi lebih asam dan sebaliknya. Kandungan asam ini juga menunjukkan tingkat kematangan buah, semakin matang buah akan semakin menurun kandungan asam yang terkandung dalam buah. Tinggi rendahnya kandungan ATT berkaitan dengan tingkat pematangan buah (Rahayu et. al., 2010).

Rasio padatan terlarut total dengan asam tertitrasi total (PTT/ATT) merupakan parameter yang digunakan untuk menentukan tingkat kematangan buah. Rasio PTT/ATT pada perlakuan aksesi berbeda nyata lebih tinggi dibanding aksesi 2 dan aksesi 3. Hal ini menunjukkan tingkat kematangan pada aksesi 1 lebih tinggi daripada aksesi lainnya. Semakin tinggi nilai rasio PTT/ATT maka semakin matang pula buah yang dihasilkan dan sering dijadikan kriteria waktu panen. Purwati et al. (1991) menyatakan bahwa rasio PTT/TAT menunjukkan peningkatan kematangan dengan semakin bertambahnya umur buah. Rasio gula/asam atau keseimbangan antara rasa manis dan asam merupakan hal yang paling penting dalam menentukan selera konsumen, jika semakin tinggi nilai rasio PTT/TAT maka buah menunjukkan rasa semakin manis (Sugiarto et al., 1991).

\section{KESIMPULAN}

Berdasarkan hasil penelitian diperoleh hasil bahwa aksesi 1 nyata lebih tinggi pada diameter, volume dan bobot buah dibanding aksesi lainnya. Kelunakan buah aksesi 1 berbeda nyata lebih rendah dibanding aksesi 3 . Aksesi 1 juga merupakan aksesi dengan tebal kulit buah paling tinggi dibanding aksesi 3 . Kandungan jus buah pada aksesi 1 juga nyata lebih tinggi dibanding aksesi 3 namun tidak berbeda dengan aksesi 2. Perbedaan aksesi menujukkan hasil tidak berbeda nyata pada BDD, kandungan klorofil, dan kandungan gula (PTT). Kandungan asam (ATT) pada aksesi 2 nyata paling tinggi dibanding aksesi lainnya, namun pada rasio PTT/ATT lebih rendah dibanding aksesi 1 . Secara keseluruhan, aksesi 1 adalah aksesi terbaik berdasarkan kriteria ukuran buah, kandungan jus, dan rasa buah yang memiliki kadar asam paling rendah.

\section{DAFTAR PUSTAKA}

[BPS] Badan Pusat Statistik. 2016. Produksi buah-buahan di Indonesia periode 20112015. [Internet] [diunduh 2016 November 26] tersedia pada https://www.bps.go.id/site/resultTab.

Kalsum, U. 2015. Perbaikan Kualitas Jeruk Pamelo (Citrus maxima (Burm.) Merr.) melalui Pengaturan Nisbah Jumlah Daun:Buah dan Pemberongsongan Buah. Tesis. Institut Pertanian Bogor. Bogor.

Keshani, S., L.A. Chuah, M.M. Nourouzi, A.R. Russly, B Jamilah. 2010. Optimization of concentration process on pomelo fruit juice using Response Surface Methodology (RSM). International Food Research Journal 17: 733-742.

Liliandra, R. 2015. Pengaruh rasio daun:buah terhadap ukuran dan kualitas buah jambu biji (Psidium guajava 1.) 'kristal'. Skripsi. Institut Pertanian Bogor. Bogor.

Mahardika, I.B.K., Susanto S. 2003. Perubahan kualitas buah beberapa kultivar jeruk besar (Citrus grandis L. (Osbeck) selama periode pematangan. J. Hayati 10: 106-109.

Muramatsu, N., T. Takahara, T. Ogata, K. Kojima. 1999. Changes in rind firmness and cell wall polysaccharides during citrus 
fruit development and maturation. J. Hort science 34 (1):79-81.

Nielson, S.S. 1998. Food Analysis-Second Edition. Indiana (US): Aspen Publisher, Inc

Oliveira, E.M.S., E.D. Resende. 2012. Yield of albedo flour and pectin content in the rind of yellow passion fruit. Ciênc. Tecnol. Aliment. Campinas 32 (3): 492-498

Purwati, S.D., T. Sabrani, H.S. Haryadi, Soemarno. 1991. Stadia pemanenan buah mangga arumanis (Yogyakarta) untuk konsumsi segar. J. Hort. 1(1):15-18.

Rahayu, A. 2012. Karakterisasi dan evaluasi aksesi pamelo (Citrus maxima (Burm.) Merr.) berbiji dan tidak berbiji asli Indonesia [vigor kekuatan tumbuh benih jeruk besar (Citrus maxima (Burm.) Merr.) untuk batang bawah] pada kondisi cekaman oksigen rendah. Disertasi. Institut Pertanian Bogor. Bogor.

Rahayu, A., S. Susanto, B.S. Purwoko, I.S Dewi. 2010. Karakter morfologi dan kimia beberapa kultivar pamelo (Citrus maxima (Burm.) Merr.) berbiji dan tanpa biji. J. Hort. Indonesia 1(1): 224-229.

Rahman, M.M., M.G. Rabbani, A.S.M.M.R. Khan, N. Ara, Rahman M.O. 2003. Study on physio-morphological characteristics of different local pummelo accessions. J. Biol Sci. 6:1430-1434.
Rodrigo, J.M., B. Alquézar, E. Alós, J. Lado, L. Zacarías. 2013. Biochemical bases and molecular regulation of pigmentation in the peel of citrus fruit. J. Scientia Horticulturae XXX (2013). 1-17.

Sims, D.A., J.A. Gamon. 2002. Relationships between leaf pigment content and spectral reflectance across a wide range of species, leaf structures and developmental stages. Remote Sensing of Environtment 81: 337 357.

Sugiarto, M., Hardianto, Suhardi. 1991. Sifat fisik dan kimiawi beberapa varietas jeruk manis (Citrus senensis L. Osbeck). J. Hort. 1(3):39-43.

Suharsi, T.K. 2000. Pendeteksian vigor kekuatan tumbuh benih jeruk besar (Citrus maxima (Burm.) Merr.) untuk batang bawah pada kondisi cekaman oksigen rendah. Disertasi. Institut Pertanian Bogor. Bogor.

Susanto, S. 2004. Perubahan kualitas buah jeruk besar (Citrus grandis (L) Osbeck) yang disimpan dan dibiarkan di pohon. J. Hayati 11: $25-28$.

Toh, J.J., H.E. Khoo, A. Azrina. 2013. Comparison of antioxidant properties of pomelo [Citrus grandis (L) Osbeck] varieties. International Food Research Journal 20(4): 1661-1668. 